observation, especially on sunspots and terrestrial magnetism, he amassed a quantity of material which it is hoped will one day be subjected to profitable analysis.

As a man, Father Rowland had great charm of manner and made many friends, and there was a whimsical mournfulness about him which never failed to amuse those who knew him intimately. He took endless pains to answer the queries of those who wrote to him for information, and in his priestly work was a zealous and sympathetic helper of souls. Towards the end of his life he became rather prematurely aged and enfeebled, and, at the close of 1947, had to retire from all active work. The end came sooner than was expected. He collapsed. and was taken to hospital on December 19, and died rather suddenly on the morning of December 26 .
WE regret to, announce the following deaths :

Prof. C. O. Bergstrand, formerly professor of astronomy in the University of Uppsala, on September 27. aged seventy-five.

Prof. Torsten Carleman, professor of mathematics in the University of Stockholm, on January 11, aged fifty-six.

Prof. Walter Garstang, emeritus professor of zoology in the University of Leeds, on February 23, aged eighty-one.

Prof. Douglas Hay, chief mining engineer (management) of the National Coal Board and president of the Institution of Mining Engineers, on February 24, aged sixty.

Prof. Richard C. Tolman, of the California Institute of Technology, vice-chairman of the U.S. National Defense Committee, on August 14, aged sixty-seven.

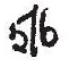

\section{The Crisis in Soviet Science}

LAST August scientific workers all over the world heard with deep disappointment that the Soviet Union had offigyly adopted an isolationist attitude on certain futheh es biology. For the first time in the UG.S.R. thefe was established a 'party line' in of of the natural sciences. Since then there has b for speculation as to whether this attitude might exten to other natural sciences, and a recent broadcast from Moscow gives point to these speculations. On January 26, 1949, the philosopher Alexander Alexandrovitch Maximov, who is a corresponding member of the Academy of Sciences, and who belongs to the staff of its Institute of Philosophy, gave a broadcast on the Moscow Radio Home Service. The theme of his talk was the correct Bolshevik attitude to natural science. He attacks those foreign physicists who "regard as synonymous the philosophical definition of matter and the objective idea of reality", and who are responsible for other "idealistic mis. interpretations" in relativity and quantum theory. He indicts by name Einstein, Niels Bohr and Heisenberg. He warns his listeners against the "Kantian acrobatics of modern bourgeois atomic physicists". He contrasts the ideology of these "social traitors" in capitalist countries with the scholars in capitalist countries who "raise their voice in support of genuine science, of a scientific materialist outlook" ; and he cites with approval Langevin, Joliot-Curie, Blackett, Haldane and Levy. The purpose of the broadcast was twofold : $(a)$ to emphasize the importance of a correct philosophical approach to physics, based on Lenin's famous "Materialism and Empiriocriticism", and $(b)$ to encourage an attitude of "militant intransigence towards bourgeois idealistic philosophy and sociology". 16

Botany at Bangor:

Prof. D. Thoday, F.R.S.

ProF. D. THOday retires from the chair of botany at the University follege of North Wales, Bangor, on Septembe $3_{3} 0^{\circ}$ After graduating at Cambridge, he caryed out researches on photosynthesis under the lat. Dr. F. F. Blackman before going to the UAvfrsity of Manchester as lecturer. Thence he befarte professor of botany at Cape Town in 1918 and returned to Bangor in 1923. Prof. Thoday has successfully combined arduous teaching duties with active research, in which he has made notable contributions in several fields-the water-relations of

\section{and VIEWS}

plants, plant development and differentiation, and the physiology of succulents. In South Africa he was much interested in the native plants, and several of his investigations concern them; in this connexion he revised the genus Passerina. He was president of Section $K$ of the British Association meeting at Dundee in 1939, when he gave a stimulating address on the interpretation of plant structure.

During his tenure at Bangor, Prof. Thoday has seen great developments in his Department, for which he has been chiefly responsible. New laboratories were built in 1926 ; but these were already congested by 1939 when, owing to the War, accommodation had also to be found for the botany students and staff of University College, London. The latter are grateful for his assistance at a critical time. Plans are now under way for a new building to house the Departments of Botany and Forestry. At Bangor there is intimate contact between these Departments and also that of Agricultural Botany, which Prof. Thoday has greatly fostered, especially as regards instruction in plant physiology and ecology. His staff have made important contributions to the ecology of North Wales and to the algal floras of the area. He has warmly supported Prof. Brambell's plea for a marine biological station on the Menai Straits, now happily being brought to fruition. Both as dean of the College faculty of science and in other ways, Prof. Thoday has taken an active part in College and University administration. On retirement, Prof. Thoday hopes to publish his researches on the developmental physiology and morphology of the mistletoe (Viscum album), on which he has been engaged for some years, and to carry out further investigations on other members of the Loranthaceæ in South Africa and elsewhere.

Prof. P. W. Richards

DR. P. W. RICHaRI fellow of Trizity wlollege, Cambridge, has been appointed to ysceed Prof. Thoday in the chair of botany Hangor. His chief interests are in plant egelogy arfd the Bryophyta, and he will have abundon pportunity for their pursuit in one of the richest reflons of Great Britain for such studies. Dr. Richards has bden a valuable member of the staff of the Cambridge Botany School since 1937, where he has been responsible for the organisation of the practical classes for first- and second-year students and has 